\title{
Morphologic characteristics of the human ciliary muscle
}

\author{
Christian Albrecht May* \\ Department of Anatomy, Medizinische Fakultät Carl Gustav Carus, TU Dresden, Germany
}

\begin{abstract}
The present review focusses on the morphological characteristics of the normal human ciliary muscle. It develops in the second and third trimenon during pregnancy but continues to change after birth with developing accommodation. The mature muscle forms three distinguishable portions which are connected but show individual characteristics. The outer portion origins and inserts with tendon-like structures, while the inner portion forms a sphincter-like appearance. The distinct different innervation is not yet completely described, nor exist portion-dependent summaries of the cytological characteristics. The specific intracellular, membraneous, and extracellular components described in the literature are listed and supplemented with own observations.
\end{abstract}

\section{Dedication}

This review is dedicated to my scientific instructors Prof. Johannes W. Rohen and Prof. Elke Lütjen-Drecoll

\section{Introduction}

Accommodation is one of the crucial conditions for foveal vision. The active change of the lens curvature is induced by the ciliary muscle, its counterpart are passive forces like the elasticity of the lens itself and of Bruch's membrane. In the present review the specifics of this muscle in the human are highlighted to better understand its unique role in the concert of uveal smooth muscle cells. Since there are known differences in the morphology and function of the ciliary muscle in different species, only data from investigations using human tissue or human cell cultures were included.

The step-wise discovery of the human ciliary muscle in the early $19^{\text {th }}$ century was only described recently [1] and is not part of this review.

\section{Three-dimensional architecture}

\section{Development}

The early development of the ciliary muscle was first described by Herzog [2] and Seefelder \& Wolfrum [3] using light microscopy of fetal human eyes; extended views were described in ophthalmic text books $[4,5]$ and a first electron-microscopic analysis was performed by Sellheyer and Spitznas [6]. According to this literature, differentiation of the human ciliary muscle starts around week 12 forming at first the outer portion (meridional portion or Brücke's muscle). The inner portion (circular portion or Müller's muscle) shows first characteristic arrangements at week 14 , the intermediate portion (radial/ reticular portion or Iwanoff's muscle) develops successively. The muscle cells and the interwoven fibroblasts derive from a common mesenchymal cell. Population present from week 10 on. Muscle cell differentiation continues up to week 16, followed by continuing maturation. First axons demonstrating an innervation of the smooth muscle cells were described in week 15. A detailed description of the development of human ciliary muscle innervation remains to be determined.

At birth, the human ciliary muscle appears still somewhat immature [7-9] and develops in the first year of life to its mature appearance. Although the different muscle portions act as one unit, distinct exposures lead to local thickness shifts in children eyes: accommodative work load stimulates the anterior (inner) part of the ciliary muscle, while the posterior (outer) part is more affected in myopic conditions [10].

\section{Mature appearance}

The mature human ciliary muscle contains of three main portions which are present in the whole circumference of the eye showing no quadrant differences. The smooth muscle cells of the outer portion are arranged from posterior to anterior (meridional), forming clear origin and insertion zones. At the posterior attachment (origin) of the outer portion, the muscle cells are mainly connected to the elastic fibers of the choroidal stroma [11-14]. The smooth muscle cells form an irregular, slender line and develop a star-like appearance [15]. The anterior attachment (insertion) of the outer portion is partly at the scleral spur, which develops early during maturation [16], and partly at the corneo-scleral portion of the trabecular meshwork [17-20]. They are attached to a special fibrous-elastic tissue which continues with elastic components of the trabecular meshwork and the scleral spur [21-23].

The smooth muscle cells of the inner portion have a circular orientation. They form bundles separated by small connective tissue sheaths. It was mentioned that it is more pronounced in the nasal quadrant [13] but a great interindividual variation could not confirm this observation. The bundles of muscle cells show some contact to the intermediate portion which connects the two main portions together and shows therefore a reticular appearance of the smooth muscle cells. A detailed description of the inner bundle arrangement of the human ciliary muscle has up to now not been published.

\section{Changes with age}

Numerous cross-sectional studies of age-related changes of the human ciliary muscle focused on its postmortal morphology and described a decrease of smooth muscle cells in combination with an

Correspondence to: Christian Albrecht May, Anatomisches Institut, Fetscherstr 74, 01307 Dresden, Germany, Tel: +49 351 4586105; Fax: +49 351 4586303; E-mail: Albrecht.May@tu-dresden.de

Key words: ciliary muscle, development, ageing, innervation, cytology Received: June 03, 2017; Accepted: June 27, 2017; Published: June 30, 2017 
increase of connective tissue. The outer portion of the ciliary muscle thereby decreased in area and length with age, while the area of the inner portion increased, adopting an anterior-inward position of the whole muscle $[7,8,16,24-29]$. The role of the intermediate portion of the ciliary muscle is discussed controversially in this literature. In vivo cross-sectional measurements using MRI [30-32], sonography [33-36], or OCT [37,38] confirmed the age-related increase in ciliary muscle area thickness without alteration of the inducible ciliary muscle activity. Findings of the ciliary ring diameter were controversially the anterior-inward position depended mainly on the state of the lens rather than the muscle itself.

\section{Innervation pattern}

Cholinergic nerve fibers are abundant in all parts of the human ciliary muscle. They form a dense neuronal network around and within the muscle fiber bundles and to a great amount do not co-localize with other specific neuronal markers like bNOS, VIP or galanin. Intense acetylcholin esterase presence was described in the anterior part of the ciliary muscle [39]; own staining using an antibody against VAChT confirmed the dense innervation throughout the muscle. Only sparse VIP immunoreactive nerve fibers exist in the ciliary muscle [40]: single nerve fibers with the typical varicose appearance were present within all portions and all regions. They probably do not supply the muscle itself [41].

Intrinsic neurons are known to exist in the human ciliary muscle since the first description by Müller 1859 . They have been confirmed subsequently, the most recent characterization dating from 1995 $[42,43]$. Their location is restricted to the inner parts of the ciliary muscle, their presence is restricted to species with high requirements for visual acuity. All neurons were NOS positive and TH/NPY/VIP negative. The somata of the neurons receive CGRP and SP positive nerve endings.

Adrenergic nerve fibers are present in the ciliary muscle, but to a much lower degree than the cholinergic nerve fibers. They have been hypothesized as early as 1891 from experiments on dogs [44] but controversially discussed thereafter. Using a fluorescence technique, the nerve fibers could be demonstrated in the human ciliary muscle [45]. Associated peptides to adrenergic nerve fibers included neuropeptide Y [46] and dopamine-beta-hydroxylase [47]. Clinical investigations confirmed the minor role of these nerves in ciliary muscle function $[48,49]$ and pronounced interindividual differences [50]. Own unpublished observations revealed only few VMAT-2 positive nerve fibers within the ciliary muscle, but no fibers containing NPY.

Substance $\mathrm{P}$ positive nerve fibers in the ciliary body were only described around blood vessels [51,52]. In contrast, Substance P was identified as a specific motor excitatory transmitter in isolated human ciliary muscle cells [53].

Sensoric (proprioceptive) nerve fibers are described in the scleral spur of human eyes representing tendon-like sensors of the outer ciliary muscle portion $[54,55]$ and in the connective tissue around the inner muscle portion [15]. Their connection to the neurons marked with calcitonin gene related peptide $[56,57]$ is not fully proven.

\section{Cytological characteristics}

\section{Intracellular components}

All human ciliary muscle cells show typical characteristic of smooth muscle cells: they stain with antibodies against alpha smooth muscle actin [20,58-61], vimentin [58,59,61], desmin [58-61], smooth muscle myosin (polyclonal antibody, no further specification so far [19]), and calponin [62]. There is no literature about the presence of calmodulin and tropomyosin in the ciliary muscle; own unpublished investigations showed that the human ciliary muscle cells do not contend caldesmon (in contrast to the description of calponin and caldesmon in the mouse ciliary muscle cells [63]).

The human ciliary muscle contains some other identified proteins: the myosin-like protein myocillin [64], the small heatshock protein alphaB-crystallin [65,66], optineurin [60], fibroleukin [60], and galanin [67]. A novel splicing variant of the regulator of G-protein signaling 5 (RGS5) was also described for the human ciliary muscle cells [68]. Some histochemical differences between the different portions of the ciliary muscle were noted earlier [69].

\section{Membrane elements and receptors}

Numerous investigations focused on the detailed interaction between the nerve fibers and the ciliary muscle cells:

After general evidence for muscarinic receptors [70,71], numerous work focused only on the subtype $\mathrm{m} 3$ [71-75], although the subtypes $\mathrm{m} 1$ and $\mathrm{m} 2$ were also detected [76]. A first localization study revealed that the muscarinic receptor subtypes $\mathrm{m} 2$ and $\mathrm{m} 3$ were predominantly in the inner portion, $\mathrm{m} 5$ predominantly in the outer portion of the ciliary muscle [77]; small amounts of the subtypes $\mathrm{m} 1$ and $\mathrm{m} 4$ were mentioned, and the presence of all subtypes $\mathrm{m} 1-\mathrm{m} 5$ with a dominance of $\mathrm{m} 3$ were confirmed [78].

The general presence of adrenergic binding sites [79] was specified to mainly beta2-adrenoceptors $[70,80,81]$, but also beta1-adrenoceptors [81] and alpha2-receptors [82,83]. A localization study showed the ubiquitous presence of beta2- and alpha1-adrenoceptors in the inner and outer portion of the ciliary muscle [84].

Additional receptors related to potential neurotransmitters and reported to be present in the human ciliary muscle include the serotonin-2 receptor [85], the cannabinoid CB1-receptor [86,87], and the galanin-receptors galR3 (ubiquitous present in the ciliary muscle) and galR1 (restricted to the inner rim of the ciliary muscle)[88].

Prostaglandin binding sites [89] are of great interest due to therapeutic application of prostaglandins. From the E-receptors, EP1 is present all over the ciliary muscle [90-92]; EP2 [93-96] and EP4 [94,96] could also be demonstrated to be present. A detailed morphologic demonstration included all four E-receptors [97]. The prostaglandin receptor FP could also be identified [60,87,90,94,98-101]; however, it is located mainly in the inner portion of the ciliary muscle [91,92,97]. Beside these two groups, the TP receptor [90] and the DP receptor $[93,95,102,103]$ were described for the human ciliary muscle; IP receptors were not mentioned.

After a first description of functional endothelin receptors in human ciliary muscle cells [104], the endothelin receptor A was identified [105-107], and less prominent also the endothelin receptor $\mathrm{B}$ [107].

Further membrane proteins described to be present in the human ciliary muscle include syndecan 1-4 [108], angiotensin receptor [70], aquaporin 1 [60], bradykinin B1 and B2 receptors [109], bradykinin B2 receptor [110], Somatostatin-receptor 1 and 2 [111], Insulin-receptor [112], type B natriuretic peptide receptor [113], and histamine 1 receptor [114]. 
A prominent characteristic of all human ciliary muscle cells is the lack of gap-junctions [115] identifying this muscle as a multiunit type of smooth muscle. Functional investigations of cultured ciliary muscle cells revealed a typical smooth-muscle like behavior [116,117].

\section{Extracellular components}

The extracellular environment around the single ciliary muscle cells is mainly investigated regarding its matrix proteins and related enzymes.

The main collagens include collagen type I and type III [118-120], type IV [118-121], type VI [120-122], and collagen type XIII [123]. While most collagens showed an even distribution within the ciliary muscle, collagen type VI was only sparse within the muscle bundles and more dominant in the outer portion towards the sclera. Additional demonstrated extracellular matrix proteins in the human ciliary muscle include fibronectin and laminin [118,120,121]; own unpublished observations showed a dense network of fibrillin and fibronectin, but only single fine vitronectin fibrils around human ciliary muscle cells.

Elastic fibers are present in the connective tissue between the muscle bundles. Staining with antibodies against elastin showed a fine network of fibers pronounced in the more anterior part of the outer portion (own unpublished observations).

Human ciliary muscle cells produce a number of enzymes including metalloproteinases [120,124-126], its tissue inhibitors TIMP-1 and TIMP-2 [127], and tissue transglutaminase (own unpublished observations). Further identified factors are IGF-1 [60], promelanosome-concentrating hormone [60], TRAIL [60], Endothelin-1 [107], kallikrein and kininogen [109], and connective tissue growth factor [128].

In connection with the prostaglandin receptor described above, some information exists about the local release of arachidonic acid and prostaglandins in cultured human ciliary muscle cells $[129,130]$.

\section{Conclusion}

Combining the described morphological characteristics, the human ciliary muscle appears as a highly specific smooth muscle with some unique characteristics. These include the three-dimensional structure of the muscle as a whole forming a mainly complete sphincter with its inner portion, the distinguishable function of different portions of the muscle, and the tendon-like attachment of the outer portion at the choroid and the scleral spur/ trabecular meshwork.

Some aspects of its morphology are already well characterized, while a more systematic investigation of the muscle is still missing. This might be caused by its specific role for accommodation and aqueous humor outflow regulation, and the focused research performed in these two respects.

Fortunately, this review stimulates some researchers to more precisely describe the normal appearance and characteristic of this exceptional muscle in the human eye, especially its three-dimensional appearance within the circumference and its multiple innervations. This might help to better understand its detailed functions, and to further discuss pathological changes and conditions involving the ciliary muscle such as presbyopia and glaucoma.

\section{Conflict of interest}

There are no conflicts of interest.

\section{References}

1. Harper DG (2014) Bringing accommodation into focus: the several discoveries of the ciliary muscle. JAMA Ophthalmol 132: 645-648. [Crossref]

2. Herzog H (1902) Über die Entwicklung der Binnenmuskulatur des Auges. Arch Mikrosk Anat 60: 517-586.

3. Seefelder R, Wolfrum C (1906) Zur Entwicklung der vorderen Kammer und des Kammerwinkels beim Menschen, nebst Bemerkungen über ihre Entstehung bei Tieren. Graefe's Arch Clin Exp Ophthalmol 63: 430-451

4. Duke-Elder S, Cook CH (1963) Normal and abnormal development. In: Duke-Elder S (ed) System of ophthalmology 3. Embryology. Mosby, St. Louis.

5. Mann I (1964) The development of the human eye, 3rd edn. Grune \& Stratton, New York.

6. Sellheyer K, Spitznas M (1988) Differentiation of the ciliary muscle in the human embryo and fetus. Graefes Arch Clin Exp Ophthalmol 226: 281-287. [Crossref]

7. Fuchs E (1928) Über den Ciliarmuskel. Graefe's Arch Clin Exp Ophthalmol 120: 735741.

8. Stieve R (1949) Über den Bau des menschlichen Ziliarmuskels, seine physiologischen Veränderungen während des Lebens und seine Bedeutung für die Akkommodation. $Z$ Mikrosk Anat Forsch 55: 3-88.

9. Zypen E van der (1970) Licht- und elektronenmikroskopische Untersuchungen über die Altersveränderungen am M. ciliaris im menschlichen Auge. Graefe's Arch Clin Exp Ophthalmol 179: 332-357.

10. Pucker AD, Sinnott LT, Kao CY, Bailey MD (2013) Region-specific relationships between refractive error and ciliary muscle thickness in children. Invest Ophthalmol Vis Sci 54: 4710-4716. [Crossref]

11. Iwanoff A, Arnold J (1874) Mikroscopische Anatomic des Uvealtraktus und der Linse. Handbuch dergesamten Augenheilkunde. Vol. 1, Grade A and Sacmisch T, editors. Leipzig. Verlag von Wilhelm Engelmann 265-320.

12. Salzmann M (1912) Anatomie und Histologie des menschlichen Augapfels im Normalzustande, seine Entwicklung und sein Altern. Leipzig, Wien, Franz Deuticke 120-124.

13. Lauber H (1936) Der Strahlenkörper (Corpus ciliare). In Handbuch der mikroskopischen Anatomie des Menschen, Haut und Sinnesorgane, Auge. Vol. 3. pt. 2. Mollendorf Wv, editor. Berlin, Springer-Verlag 134-176.

14. Rohen JW (1952) Der Ziliarkörper als funktionelles System. Gegenbaurs Morphol Jahrb 92: 415.

15. Flügel-Koch C, Neuhuber WL, Kaufman PL, Lütjen-Drecoll E (2009) Morphologic indication for proprioception in the human ciliary muscle. Invest Ophthalmol Vis Sci 50: 5529-5536. [Crossref]

16. Hamanaka T (1989) Scleral spur and ciliary muscle in man and monkey. Jpn $J$ Ophthalmol 33: 221-236. [Crossref]

17. Rohen J (1956) [Insertion of the ciliary muscle in the region of the angle of the anterior chamber. III. Morphological study of the problem of aqueous humor circulation]. Ophthalmologica 131: 51-60. [Crossref]

18. Kupfer C (1962) Relationship of ciliary body meridional muscle and corneoscleral trabecular meshwork. Arch Ophthalmol 68: 818-822. [Crossref]

19. de Kater AW, Spurr-Michaud SJ, Gipson IK (1990) Localization of smooth muscle myosin-containing cells in the aqueous outflow pathway. Invest Ophthalmol Vis Sci 31: 347-353. [Crossref]

20. de Kater AW, Shahsafaei A, Epstein DL (1992) Localization of smooth muscle and nonmuscle actin isoforms in the human aqueous outflow pathway. Invest Ophthalmol Vis Sci 33: 424-429. [Crossref]

21. Moses RA, Grodzki WJ Jr (1977) The scleral spur and scleral roll. Invest Ophthalmol Vis Sci 16: 925-931. [Crossref]

22. Tamm E, Flügel C, Stefani FH, Rohen JW (1992) Contractile cells in the human scleral spur. Exp Eye Res 54: 531-543. [Crossref]

23. Park CY, Lee JK, Kahook MY, Schultz JS, Zhang C, et al. (2016) Revisiting ciliary muscle tendons and their connections with the trabecular meshwork by two photon excitation microscopic imaging. Invest Ophthalmol Vis Sci 57: 1096-105. [Crossref]

24. Rother P, Blume R, Friedrich H, Lochner M (1971) Die Veränderung der MuskelBindegewebs-Relation des Musculus ciliaris im Laufe des Lebens. Anat Anz 129: 322-332. 
25. Blume R, Rother P, Lochner M (1971) Lineare Differentialgleichungen zur Beschreibung der histologischen Biomorphose des menschlichen Ciliarmuskels. Z Alternsforsch 23: 235-242.

26. Schlötzer-Schrehardt U, Wirtz PM, Müller HG, Lang GK, Naumann GO (1990) Morphometrische Analyse altersabhängiger Veränderungen des menschlichen Ziliarkörpers. Fortschr Ophthalmol 87: 59-68.

27. Tamm S, Tamm E, Rohen JW (1992) Age-related changes of the human ciliary muscle. A quantitative morphometric study. Mech Ageing Dev 62: 209-221. [Crossref]

28. Nishida S, Mizutani S (1992) Quantitative and morphometric studies of age-related changes in human ciliary muscle. Jpn J Ophthalmol 36: 380-387. [Crossref]

29. Pardue MT, Sivak JG (2000) Age-related changes in human ciliary muscle. Optom Vis Sci 77: 204-210. [Crossref]

30. Strenk SA, Semmlow JL, Strenk LM, Munoz P, Gronlund-Jacob J, et al. (1999) Agerelated changes in human ciliary muscle and lens: a magnetic resonance imaging study. Invest Ophthalmol Vis Sci 40: 1162-1169. [Crossref]

31. Strenk SA, Strenk LM, Guo S (2006) Magnetic resonance imaging of aging, accommodating, phakic, and pseudophakic ciliary muscle diameters. $J$ Cataract Refract Surg 32: 1792-1798. [Crossref]

32. Strenk SA, Strenk LM, Guo S (2010) Magnetic resonance imaging of the anteroposterior position and thickness of the aging, accommodating, phakic, and pseudophakic ciliary muscle. J Cataract Refract Surg 36: 235-241. [Crossref]

33. Bacskulin A, Martin H, Kundt G, Terwee T, Guthoff R (2000) [Analysis of the dynamics of the ciliary muscle during accommodation]. Ophthalmologe 97: 855-859. [Crossref]

34. Stachs O, Martin H, Kirchhoff A, Stave J, Terwee T, et al. (2002) Monitoring accommodative ciliary muscle function using three-dimensional ultrasound. Graefes Arch Clin Exp Ophthalmol 240: 906-912. [Crossref]

35. Richdale K, Sinnott LT, Bullimore MA, Wassenaar PA, Schmalbrock P, et al. (2013) Quantification of age-related and per diopter accommodative changes of the lens and ciliary muscle in the emmetropic human eye. Invest Ophthalmol Vis Sci 54: 1095-1105. [Crossref]

36. Croft MA, McDonald JP, Katz A, Lin TL, Lütjen-Drecoll E, et al. (2013) Extralenticular and lenticular aspects of accommodation and presbyopia in human versus monkey eyes. Invest Ophthalmol Vis Sci 54: 5035-5048. [Crossref]

37. Sheppard AL, Davies LN (2011) The effect of ageing on in vivo human ciliary muscle morphology and contractility. Invest Ophthalmol Vis Sci 52: 1809-1816. [Crossref]

38. Shao Y, Tao A, Jiang H, Mao X, Zhong J, et al. (2015) Age-related changes in the anterior segment biometry during accommodation. Invest Ophthalmol Vis Sci 56: 35223530. [Crossref]

39. Tamm ER, Koch TA, Mayer B, Stefani FH, Lütjen-Drecoll E (1995) Innervation of myofibroblast-like scleral spur cells in human monkey eyes. Invest Ophthalmol Vis Sci 36: 1633-1644. [Crossref]

40. Stone RA, Tervo T, Tervo K, Tarkkanen A (1986) Vasoactive intestinal polypeptidelike immunoreactive nerves to the human eye. Acta Ophthalmol (Copenh) 64: 12-18.

41. Miller AS, Fraco DJC, Costa Laurea M, MSC JBF (1983) Vasoactive intestinal polypeptide immunoreactive nerve fibres in the human eye. Austr J Opthalmol 11:185193. [Crossref]

42. Tamm ER, Flügel-Koch C, Mayer B, Lütjen-Drecoll E (1995) Nerve cells in the human ciliary muscle: ultrastructural and immunocytochemical characterization. Invest Ophthalmol Vis Sci 36: 414-426. [Crossref]

43. Nathanson JA, McKee M (1995) Identification of an extensive system of nitric oxideproducing cells in the ciliary muscle and outflow pathway of the human eye. Invest Ophthalmol Vis Sci 36: 1765-1773. [Crossref]

44. Morat JP, Doyon M (1891) L'Oculomoteur, qui adapte l'oeil pour la vision des objets rapprochés et le grand sympathique qui l'adapte pour la vision des objets eloignés. Arch de Physiologie 509.

45. Ehinger B (1966) Adrenergic nerves to the eye and to related structures in man and in the cynomolgus monkey. Invest Ophthalmol Vis Sci 5: 42-52.

46. Stone RA (1986) Neuropeptide $\mathrm{Y}$ and the innervation of the human eye. Exp Eye Res 42: 349-355. [Crossref]

47. Chen Z, Jia W, Kaufman PL, Cynader M (1999) Immunohistochemical localization of dopamine-beta-hydroxylase in human and monkey eyes. Curr Eye Res 18: 39-48. [Crossref]
48. Langham ME, Kitazawa Y, Hart RW (1971) Adrenergic responses in the human eye. $J$ Pharmacol Exp Ther 179: 47-55. [Crossref]

49. Mallen EA, Gilmartin B, Wolffsohn JS (2005) Sympathetic innervation of ciliary muscle and oculomotor function in emmetropic and myopic young adults. Vision Res 45: 1641-1651. [Crossref]

50. Gilmartin B, Mallen EA, Wolffsohn JS (2002) Sympathetic control of accommodation: evidence for inter-subject variation. Ophthalmic Physiol Opt 22: 366-371. [Crossref]

51. Tervo T, Tervo K, Eränkö L (1982) Ocular neuropeptides. Med Biol 60: 53-60. [Crossref]

52. Stone RA, Kuwayama Y (1985) Substance P-like immunoreactive nerves in the human eye. Arch Ophthalmol 103: 1207-1211. [Crossref]

53. Lograno MD, Daniele E (1988) Substance P as a transmitter in the human ciliary muscle. Pharmacol Res Commun 20: 901-905. [Crossref]

54. Tamm ER, Flügel C, Stefani FH, Lütjen-Drecoll E (1994) Nerve endings with structural characteristics of mechanoreceptors in the human scleral spur. Invest Ophthalmol Vis Sci 35: 1157-1166. [Crossref]

55. Selbach JM, Gottanka J, Wittmann M, Lütjen-Drecoll E (2000) Efferent and afferent innervation of primate trabecular meshwork and scleral spur. Invest Ophthalmol Vis Sci 41: 2184-2191. [Crossref]

56. Uusitalo H, Krootila K, Palkama A (1989) Calcitonin gene-related peptide (CGRP) immunoreactive sensory nerves in the human and guinea pig uvea and cornea. Exp Eye Res 48: 467-475. [Crossref]

57. Stone RA, McGlinn AM (1988) Calcitonin gene-related peptide immunoreactive nerves in human and rhesus monkey eyes. Invest Ophthalmol Vis Sci 29: 305-310. [Crossref]

58. Tamm E, Flügel C, Baur A, Lütjen-Drecoll E (1991) Cell cultures of human ciliary muscle: growth, ultrastructural and immunocytochemical characteristics. Exp Eye Res 53: 375-387. [Crossref]

59. Kivelä T, Fuchs U, Tarkkanen A (1992) Cytoskeleton in neuroectodermally derived epithelial and muscle cells of the human iris and ciliary body. J Histochem Cytochem 40: 1517-1526. [Crossref]

60. Zhao X, Pearson KE, Stephan DA, Russell P (2003) Effects of prostaglandin analogues on human ciliary muscle and trabecular meshwork cells. Invest Ophthalmol Vis Sci 44 1945-1952. [Crossref]

61. Uusitalo M, Kivelä T (1995) Development of cytoskeleton in neuroectodermally derived epithelial and muscle cells of the human eye. Invest Ophthalmol Vis Sci 36: 2584-2591. [Crossref]

62. Kashiwagi K, Lindsey JD, Kashiwagi F, Tsukahara S, Weinreb RN (1997) Calponin distribution in human ciliary muscle and other anterior segment tissues. Invest Ophthalmol Vis Sci 38: 349-356. [Crossref]

63. Ko MK, Tan JC (2013) Contractile markers distinguish structures of the mouse aqueous drainage tract. Mol Vis 19: 2561-2570. [Crossref]

64. Karali A, Russell P, Stefani FH, Tamm ER (2000) Localization of myocilin/trabecular meshwork--inducible glucocorticoid response protein in the human eye. Invest Ophthalmol Vis Sci 41: 729-740. [Crossref]

65. Siegner A, May CA, Welge-Lüssen UW, Bloemendal H, Lütjen-Drecoll E (1996) alpha B-crystallin in the primate ciliary muscle and trabecular meshwork. Eur J Cell Biol 71: 165-169. [Crossref]

66. Welge-Lüssen U, Bloemendal H, Lütjen-Drecoll E (2000) Transforming growth factorbeta: a growth factor inducing alpha B-crystallin expression in ciliary muscle cells. Graefes Arch Clin Exp Ophthalmol 238: 993-997. [Crossref]

67. Kaser-Eichberger A, Trost A, Strohmaier C, Bogner B, Runge C, et al. (2016) Distribution of the neuro-regulatory peptide galanin in the human eye. Neuropeptides. [Crossref]

68. Liang Y, Li C, Guzman VM, Chang WW, Evinger AJ 3rd, et al. (2005) Identification of a novel alternative splicing variant of RGS5 mRNA in human ocular tissues. FEBS $J$ 272: 791-799. [Crossref]

69. Flügel C, Bárány EH, Lütjen-Drecoll E (1990) Histochemical differences within the ciliary muscle and its function in accommodation. Exp Eye Res 50: 219-226. [Crossref]

70. Lograno MD, Reibaldi A (1986) Receptor-responses in fresh human ciliary muscle. $\mathrm{Br}$ J Pharmacol 87: 379-385. [Crossref]

71. Pang IH, Matsumoto S, Tamm E, DeSantis L (1994) Characterization of muscarinic receptor involvement in human ciliary muscle cell function. J Ocul Pharmacol 10 : 125-136. [Crossref] 
72. Woldemussie E, Feldmann BJ, Chen J (1993) Characterization of muscarinic receptors in cultured human iris sphincter and ciliary smooth muscle cells. Exp Eye Res 56: 385392. [Crossref]

73. Gupta N, Drance SM, McAllister R, Prasad S, Rootman J, et al. (1994) Localization of M3 muscarinic receptor subtype and mRNA in the human eye. Ophthalmic Res 26 : 207-213. [Crossref]

74. Matsumoto S, Yorio T, DeSantis L, Pang IH (1994) Muscarinic effects on cellular functions in cultured human ciliary muscle cells. Invest Ophthalmol Vis Sci 35: 3732 3738. [Crossref]

75. Zhang X, Schroeder A, Erickson KA (1999) Effect of continuous administration of a cholinergic agonist on $[3 \mathrm{H}] 4-\mathrm{DAMP}$ binding and $\mathrm{m} 3 \mathrm{mRNA}$ expression in cultured human ciliary muscle cells. J Ocul Pharmacol Ther 15: 153-163. [Crossref]

76. Gupta N, McAllister R, Drance SM, Rootman J, Cynader MS (1994) Muscarinic receptor M1 and M2 subtypes in the human eye: QNB, pirenzipine, oxotremorine, and AFDX-116 in vitro autoradiography. Br J Ophthalmol 78: 555-559. [Crossref]

77. Zhang X, Hernandez MR, Yang H, Erickson K (1995) Expression of muscarinic receptor subtype mRNA in the human ciliary muscle. Invest Ophthalmol Vis Sci 36: 1645-1657. [Crossref]

78. Gil DW, Krauss HA, Bogardus AM, WoldeMussie E (1997) Muscarinic Receptor Subtypes in Human Iris-Ciliary Body Measured by Immunoprecipitation. Invest Ophthalmol Vis Sci 38: 1434-1442. [Crossref]

79. Elena PP, Denis P, Kosina-Boix M, Saraux H, Lapalus P (1990) Beta adrenergic binding sites in the human eye: an autoradiographic study. J Ocul Pharmacol 6: 143149. [Crossref]

80. van Alphen GW (1976) The adrenergic receptors of the intraocular muscles of the human eye. Invest Ophthalmol 15: 502-505. [Crossref]

81. Wax MB, Molinoff PB (1987) Distribution and properties of beta-adrenergic receptors in human iris-ciliary body. Invest Ophthalmol Vis Sci 28: 420-430. [Crossref]

82. Huang Y, Gil DW, Vanscheeuwijck P, Stamer WD, Regan JW (1995) Localization of alpha 2-adrenergic receptor subtypes in the anterior segment of the human eye with selective antibodies. Invest Ophthalmol Vis Sci 36: 2729-2739. [Crossref]

83. Ooi YH, Oh DJ, Rhee DJ (2009) Analysis of alpha2-adrenergic receptors and effect of brimonidine on matrix metalloproteinases and their inhibitors in human ciliary body. Invest Ophthalmol Vis Sci 50: 4237-4243. [Crossref]

84. Zetterström C, Hahnenberger R (1988) Pharmacological Characterization of Human Ciliary Muscle Adrenoceptors In Vitro. Exp Eye Res 46: 421-430. [Crossref]

85. Sharif NA, Kelly CR, Crider JY, Davis TL (2006) Serotonin-2 (5-HT2) receptormediated signal transduction in human ciliary muscle cells: role in ocular hypotension. J Ocul Pharmacol Ther 22: 389-401. [Crossref]

86. Straiker AJ, Maguire G, Mackie K, Lindsey J (1999) Localization of cannabinoid CB1 receptors in the human anterior eye and retina. Invest Ophthalmol Vis Sci 40: 24422448. [Crossref]

87. Romano MR, Lograno MD (2007) Evidence for the involvement of cannabinoid CB1 receptors in the bimatoprost-induced contractions on the human isolated ciliary muscle. Invest Ophthalmol Vis Sci 48: 3677-3682. [Crossref]

88. Schrödl F, Kaser-Eichberger A, Trost A, Strohmaier C, Bogner B, et al. (2015) Distribution of galanin receptors in the human eye. Exp Eye Res 138: 42-51. [Crossref]

89. Matsuo T, Cynader MS (1992) Localisation of prostaglandin F2 alpha and E2 binding sites in the human eye. Br J Ophthalmol 76: 210-213. [Crossref]

90. Chen W, Andom T, Bhattacherjee P, Paterson C (1997) Intracellular calcium mobilization following prostaglandin receptor activation in human ciliary muscle cells, Curr Eye Res 16: 847-853. [Crossref]

91. Mukhopadhyay P, Bian L, Yin H, Bhattacherjee P, Paterson C (2001) Localization of $\mathrm{EP}(1)$ and FP receptors in human ocular tissues by in situ hybridization. Invest Ophthalmol Vis Sci 42: 424-428. [Crossref]

92. Zhang Z, Yin H (2002) Detection of EP1 and FP receptor mRNAs in the iris-ciliary body using in situ hybridization. Chin Med J (Engl) 115: 1226-1228. [Crossref]

93. Matsuo T, Cynader MS (1993) The EP2 receptor is the predominant prostanoid receptor in the human ciliary muscle. Br J Ophthalmol 77: 110-114. [Crossref]

94. Mukhopadhyay P, Geoghegan TE, Patil RV, Bhattacherjee P, Paterson CA (1997) Detection of EP2, EP4, and FP receptors in human ciliary epithelial and ciliary muscle cells. Biochem Pharmacol 53: 1249-1255. [Crossref]
95. Sharif NA, Williams GW, Crider JY, Xu SX, Davis TL (2004) Molecular pharmacology of the DP/EP2 class prostaglandin AL-6598 and quantitative autoradiographic visualization of DP and EP2 receptor sites in human eyes. J Ocul Pharmacol Ther 20: 489-508. [Crossref]

96. Reitmair A, Lambrecht NW, Yakubov I, Nieves A, Old D, et al. (2010) Prostaglandin E2 receptor subtype EP2- and EP4-regulated gene expression profiling in human ciliary smooth muscle cells. Physiol Genomics 42: 348-360. [Crossref]

97. Schlötzer-Schrehardt U, Zenkel M, Nüsing RM (2002) Expression and localization of $\mathrm{fp}$ and ep prostanoid receptor subtypes in human ocular tissues. Invest Ophthalmol Vis Sci 43: 1475-1487. [Crossref]

98. Sharif NA, Davis TL, Williams GW (1999) [3H]AL-5848 ([3H]9beta- $(+)$ Fluprostenol). Carboxylic acid of travoprost (AL-6221), a novel FP prostaglandin to study the pharmacology and autoradiographic localization of the FP receptor. $J$ Pharm Pharmacol 51: 685-694. [Crossref]

99. Davis TL, Sharif NA (1999) Quantitative autoradiographic visualization and pharmacology of FP-prostaglandin receptors in human eyes using the novel phosphorimaging technology. J Ocul Pharmacol Ther 15: 323-336. [Crossref]

100. Sharif NA, Kelly CR, Crider JY, Williams GW, Xu SX (2003) Ocular hypotensive FP prostaglandin (PG) analogs: PG receptor subtype binding affinities and selectivities, and agonist potencies at FP and other PG receptors in cultured cells. $J$ Ocul Pharmacol Ther 19: 501-515. [Crossref]

101. Hutchinson AJ, Coons SC, Chou CL, Xu W, Stamer WD, et al. (2010) Induction of angiogenic immediate early genes by activation of FP prostanoid receptors in cultured human ciliary smooth muscle cells. Curr Eye Res 35: 408-418. [Crossref]

102. Sharif NA, Williams GW, Davis TL (2000) Pharmacology and autoradiography of human DP prostanoid receptors using [(3)H]-BWA868C, a DP receptor-selective antagonist radioligand. Br J Pharmacol 131: 1025-1038. [Crossref]

103. Sharif NA, Davis TL, Williams GW (2005) Ocular hypotensive DP-class prostaglandin receptor affinities determined by quantitative autoradiography on human eye sections. J Ocul Pharmacol Ther 21: 121-132. [Crossref]

104. Korbmacher C, Helbig H, Haller H, Erickson-Lamy KA, Wiederholt M (1989) Endothelin depolarizes membrane voltage and increases intracellular calcium concentration in human ciliary muscle cells. Biochem Biophys Res Commun 164: 1031-1039. [Crossref]

105. Matsumoto S, Yorio T, Magnino PE, DeSantis L, Pang IH (1996) Endothelininduced changes of second messengers in cultured human ciliary muscle cells. Invest Ophthalmol Vis Sci 37: 1058-1066. [Crossref]

106. Tao W, Prasanna G, Dimitrijevich S, Yorio T (1998) Endothelin receptor A is expressed and mediates the $[\mathrm{Ca} 2+]$ i mobilization of cells in human ciliary smooth muscle, ciliary nonpigmented epithelium, and trabecular meshwork. Curr. Eye Res 17: 31-38. [Crossref]

107. Fernández-Durango R, Rollín R, Mediero A, Roldán-Pallares M, García Feijo J, et al. (2003) Localization of endothelin-1 mRNA expression and immunoreactivity in the anterior segment of human eye: expression of ETA and ETB receptors. Mol Vis 9: 103-109. [Crossref]

108. Filla MS, David G, Weinreb RN, Kaufman PL, Peters DM (2004) Distribution of syndecans 1-4 within the anterior segment of the human eye: expression of a variant syndecan-3 and matrix-associated syndecan-2. Exp Eye Res 79: 61-74. [Crossref]

109. Ma JX, Song Q, Hatcher HC, Crouch RK, Chao L, et al. (1996) Expression and cellular localization of the kallikrein-kinin system in human ocular tissues. Exp Eye Res 63: 19-26. [Crossref]

110. Sharif NA, Xu S, Li L, Katoli P, Kelly CR, et al. (2013) Protein expression, biochemical pharmacology of signal transduction, and relation to intraocular pressure modulation by bradykinin B2 receptors in ciliary muscle. Mol Vis 19: 1356-1370. [Crossref]

111. Klisovic DD, O’Dorisio MS, Katz SE, Sall JW, Balster D, et al. (2001) Somatostatin receptor gene expression in human ocular tissues: RT-PCR and immunohistochemical study. Invest Ophthalmol Vis Sci 42: 2193-2201. [Crossref]

112. Naeser P (1997) Insulin receptors in human ocular tissues. Immunohistochemica demonstration in normal and diabetic eyes. Ups J Med Sci 102: 35-40. [Crossref]

113. Pang IH, Shade DL, Matsumoto S, Steely HT, DeSantis L (1996) Presence of functional type B natriuretic peptide receptor in human ocular cells. Invest Ophthalmol Vis Sci 37: 1724-1731. [Crossref]

114. Markwardt KL, Magnino PE, Pang IH (1996) Effect of histamine on phosphoinositide turnover and intracellular calcium in human ciliary muscle cells. Exp Eye Res 62 : 511-520. [Crossref] 
115. Samuel U, Lütjen-Drecoll E, Tamm ER (1996) Gap junctions are found between iris sphincter smooth muscle cells but not in the ciliary muscle of human and monkey eyes. Exp Eye Res 63: 187-192.

116. Korbmacher C, Helbig H, Coroneo M, Erickson-Lamy KA, Stiemer B, et al. (1990) Membrane voltage recordings in a cell line derived from human ciliary muscle. Invest Ophthalmol Vis Sci 31: 2420-2430. [Crossref]

117. Stahl F, Lepple-Wienhues A, Kuppinger M, Schneider U, Wiederholt M (1991) Measurements of intracellular calcium and contractility in human ciliary muscle. Pflugers Arch 418: 531-537. [Crossref]

118. Weinreb RN, Lindsey JD, Luo XX, Wang TH (1994) Extracellular matrix of the human ciliary muscle. J Glaucoma 3: 70-78. [Crossref]

119. Lindsey JD, Kashiwagi K, Kashiwagi F, Weinreb RN (1997) Prostaglandins alter extracellular matrix adjacent to human ciliary muscle cells in vitro. Invest Ophthalmol Vis Sci 38: 2214-2223. [Crossref]

120. Ocklind A (1998) Effect of latanoprost on the extracellular matrix of the ciliary muscle. A study on cultured cells and tissue sections. Exp Eye Res 67: 179-191. [Crossref]

121. Tamm E, Baur A, Lütjen-Drecoll E (1992) Synthesis of extracellular matrix components by human ciliary muscle cells in culture. Curr Eye Res 11: 333-341. [Crossref]

122. Rittig M, Lütjen-Drecoll E, Rauterberg J, Jander R, Mollenhauer J (1990) Type-VI collagen in the human iris and ciliary body. Cell Tissue Res 259: 305-312. [Crossref]
123. Sandberg-Lall M, Hägg PO, Wahlström I, Pihlajaniemi T (2000) Type XIII collagen is widely expressed in the adult and developing human eye and accentuated in the ciliary muscle, the optic nerve and the neural retina. Exp Eye Res 70: 401-410. [Crossref]

124. Lindsey JD, Kashiwagi K, Kashiwagi F, Weinreb RN (1997) Prostaglandin action on ciliary smooth muscle extracellular matrix metabolism: implications for uveoscleral outflow. Surv Ophthalmol 41 Supp1 2: S53-59. [Crossref]

125. Weinreb RN, Kashiwagi K, Kashiwagi F, Tsukahara S, Lindsey JD (1997) Prostaglandins increase matrix metalloproteinase release from human ciliary smooth muscle cells. Invest Ophthalmol Vis Sci 38: 2772-2780. [Crossref]

126. Husain S, Jafri F, Crosson CE (2005) Acute effects of PGF2alpha on MMP-2 secretion from human ciliary muscle cells: a PKC- and ERK-dependent process. Invest Ophthalmol Vis Sci 46: 1706-1713. [Crossref]

127. Anthony TL, Lindsey JD, Weinreb RN (2002) Latanoprost's effects on TIMP-1 and TIMP-2 expression in human ciliary muscle cells. Invest Ophthalmol Vis Sci 43: 3705-3711. [Crossref]

128. van Setten GB, Trost A, Schrödl F, Kaser-Eichberger A, et al. (2016) Immunohistochemical Detection of CTGF in the Human Eye. Curr Eye Res 41 : 1571-1579. [Crossref]

129. Yousufzai SY, Abdel-latif AA (1997) Endothelin-1 stimulates the release of arachidonic acid and prostaglandins in cultured human ciliary muscle cells: activation of phospholipase A2. Exp Eye Res 65: 73-81. [Crossref]

130. Husain S, Kaddour-Djebbar I, Abdel-Latif AA (2002) Alterations in arachidonic acid release and phospholipase C-beta (1) expression in glaucomatous human ciliary muscle cells. Invest Ophthalmol Vis Sci 43: 1127-1134. [Crossref]

Copyright: (C2017 May CA. This is an open-access article distributed under the terms of the Creative Commons Attribution License, which permits unrestricted use, distribution, and reproduction in any medium, provided the original author and source are credited. 